\title{
Effect of Temperature on Active and Resting Metabolism in Polychaetes
}

Philip Exton Coyer

College of William \& Mary - Arts \& Sciences

Follow this and additional works at: https://scholarworks.wm.edu/etd

Part of the Physiology Commons

\section{Recommended Citation}

Coyer, Philip Exton, "Effect of Temperature on Active and Resting Metabolism in Polychaetes" (1972). Dissertations, Theses, and Masters Projects. Paper 1539624763.

https://dx.doi.org/doi:10.21220/s2-hpjs-ag83

This Thesis is brought to you for free and open access by the Theses, Dissertations, \& Master Projects at W\&M ScholarWorks. It has been accepted for inclusion in Dissertations, Theses, and Masters Projects by an authorized administrator of W\&M ScholarWorks. For more information, please contact scholarworks@wm.edu. 


\title{
EFFECT OF TEMPERATURE ON ACTIVE
}

\section{AND RESTING METABOLISM IN POLYCHAETES}

\begin{abstract}
A Thesis
Presented to

The Faculty of the Department of Biology

The College of William and Mary in Virginia
\end{abstract}

In Partial Fulfillment

of the Requirements for the Degree of

Master of Arts

by

Philip E. Coyer

1972 
APPROVAL SHEET

This thesis is submitted in partial fulfillment of the requirements for the degree of

Master of Arts

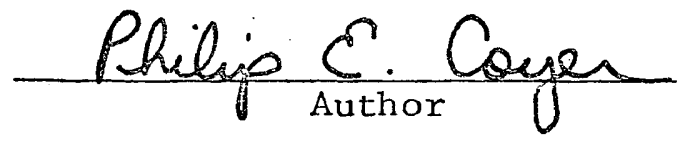

Approved, August 1972
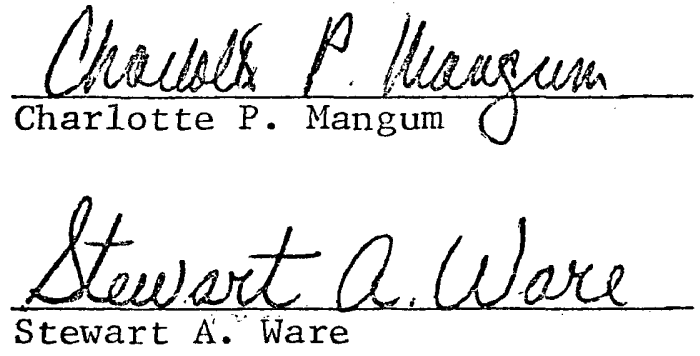

David D. Dow

David D. Dow 
TABIE OF CONTENTS

Page

ACKNOWLEDGMENTS . . . . . . . . . . . . . . iv IIST OF FIGURES . • . . . . . . . • . . . . • v ABSTRACT. . . . . . . . . . . . . . . . . vi v INTRODUCTION . . . . . . . . . . . . . . 2 MATERIALS AND METHODS ............... 4

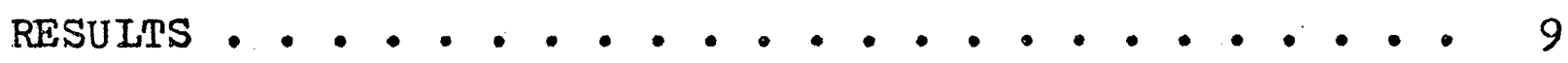

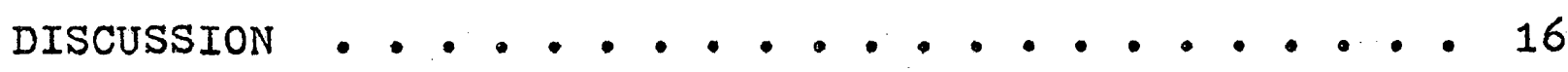
BIBIIOGRAPHY . . . . . . . . . . . . 18 
ACKNOWLEDGMENTS

The author wishes to express his sincere appreciation to Dr. Charlotte P. Mangum whose enthusiastic help and perceptive comments made this investigation possible. I also wish to thank Dr. Stewart A. Ware and Dr. David D. Dow for their critical reading of this manuscript. Mr. Glen Bean provided the technical assistance needed in designing and building apparatus used in this work. My deepest regard goes to my wife Susan who was always encouraging and understanding during this study. 


\section{IIST OF FIGURES}

Figure

1. R.T. curves for active and resting metabolism in Diopatra cuprea . . . 12

2. R.T. curves for active and resting metabolism in Glycera dibranchiata. . 13

3. R.T. curves for active and resting metabolism in Amphitrite ornata . . 14

4. Kymograph record of ventilation $f$ frequencies in Amphitrite ornata. . 15 


\section{ABSTRACT}

Using species representing three families of polychaetous annelids, the following postulate was investigated resting metabolism of intertidal invertebrate organisms remains thermally insensitive over a wide environmental range. Polychaetes were chosen as representative animals because of their characteristic ventilatory patterns of activity and rest which result in rapid and slow rates of oxygen consumption. $Q_{10}$ values for active and resting metabolism of the three species Diopatra cuprea, Glycera dibranchiata, and Amphitrite ornata were computed over 20-250 $\mathrm{C}$ temperature ranges. Me tabolic rates of two species had been related previously to phases of their behavior cycles during tube irrigation. The relationship between active and resting metabolism and natural activity patterns of the third species, Amphitrite ornata, was established in this study. Substantial thermal compensation was observed over several $5^{\circ} \mathrm{C}$ intervals. However, no $Q_{10}$ values as low as 1.0 were found over $20^{\circ} \mathrm{C}$ ranges for the resting metabolism of these intertidal organisms. 
EFFECT OF TEMPERATURE ON ACTIVE AND RESTING METABOLISM IN POLYCHAETES 


\section{INTRODUCTION}

Newell and Northcroft (1967) concluded that the minimal rate of oxygen consumption corresponding to a resting phase in four intertidal species, the lamellibranch Cardium edule, the actinian Actinia equina, the polychaete Nepthys hombergi, and the gastropod Littorina littorea, is thermally insensitive over the temperature range $5-22 \cdot 5^{\circ} \mathrm{C}$. Newell (1967) also presented evidence for varying degrees of temperature independence of mitochondrial oxidative activity in subtidal, intextidal, and terrestrial poikilotherms. Since this hypothesis was made, only Mangum and Sassaman (1969) have related independently measured activity patterns to oxygen consumption data to identify active and resting metabolic phases. Nimura and Inoue (1969), Tribe and Bowler (1968), and Halcrow and Boyd (1967) described methods of determining the metabolic rate in various marine and terrestrial invertebrates at low muscular activity levels. However these methods either involve anaesthetization, extrapolation from higher activity levels or presumably intermittent visual observation of the activity level. Recently, conflicting conclusions on the temperature coefficients for inactive metabolic rates were reached by Wallace (1972) and Lowe and Trueman (1972). 
Characteristic patterns of alternating activity and rest comprise the ventilation rhythms of many polychaetous annelids, including the onuphid Diopatra cuprea (Bosc) and the glycerid Glycera dibranchiata (Ehlers), whose behavior results in rapid and slow rates of oxygen consumption (Mangum and Sassaman, 1969; Hoffman and Mangum, 1970). Since Mangum and Sassaman (1969) described thermal sensitivity of active and resting metabolism in D. cuprea only over a $10^{\circ} \mathrm{C}$ interval, this species has been further investigated over a wider range. In addition, G. dibranchiata and the terebellid Amphitrite ornata (Leidy) were chosen for study of the effects of temperature on what is unequivocally active and resting metabolism in these intertidal organisms. 
MATERIALS AND METHODS

I. Oxygen consumption

Although Newell and Northcroft (1967) based their conclusions on acute measurements of metabolism, we have used acclimated measurements for two reasons: 1) Temperature shock dismupts the pattern of spontaneous rhythmic activity resulting in loss of identifiable phases of metabolism. At least in $\underline{\text {. }}$ cuprea, the acclimation which ensues involves the behavior pattern but not aerobic metabolism (Mangum, 1972). 2) We believe that temperature changes occur in nature at a rate that is small enough so that the animal can simultaneously acclimate to them (Johnson, 1965; Mangum and Sassaman, 1969). Therefore, acclimated measurements have more pertinence to the responses of infaunal, tubicalous annelids, even those in intertidal habitats.

Active and resting oxygen consumption rates for three species of polychaetous annelids Diopatra cuprea, Glycera dibranchiata, and Amphitrite ornata were computed using the technique described by Mangum and Sassaman (1969). The animals were pre-exposed in the laboratory to each experimental temperature for a minimum of five days and a maximum of two weeks, depending on the departure from habitat temperature. During the period of exposure, the animal was 
placed in a glass tube whose length just barely exceeded that of the worm. Continuous recordings of oxygen depletion by D. cuprea were made in lucite chambers with the animal lying horizontally. G. dibranchiata was placed in cylindrical chambers with the animal orjented vertically. And finally, A. ornata was put in rectangular chambers housing a U-shaped tube. Measurements of oxygen consumption at oxygen concentrations above $75 \%$ air saturation were made in Milliporefiltered sea water (salinity $15 \cdot 2-17 \cdot 4 \%$ ), to which the animal was adapted, and at constant temperatures $\left( \pm 0.5^{\circ} \mathrm{C}\right)$. As a control, the oxygen consumption rate of the probe itself was measured and subtracted from those of the animals; the observed amount was barely detectable, viz., less than $1 \%$ of the existing oxygen concentration. Recordings of oxygen consumption were made with a Yellow Springs Model 5420A probe and Model 54 meter. Both active and resting metabolic rates for the three species were corrected to common weights using the covariance method of adjusting treatment means (Steel and Torrie, 1960).

A. Diopatra cuprea

Collections of ragworms were made from August through October 1971 in the intertidal zone of the York River estuary at Sandy Point, Virginia. Five to twelve animals were measured at each of three temperatures $12.5,22.5$, and $32.5^{\circ} \mathrm{C}$, the highest reached by stepwise acclimation of ${ }^{\circ} \mathrm{C}$ per day from lower collecting temperatures. Values for the slope of the logarithmic regression line describing metabolism as a function of body weight were extracted from 
the results of Mangum and Sassaman (1969) at 17.5 and $27.5^{\circ} \mathrm{C}$ to correct oxygen consumption rates to a common weight of $0.88 \mathrm{gm}$, which is the value that they used.

B. Glycera dibranchiata

Bloodworms were obtained during the winter months from the Maine Bait Company. Upon arrival they were kept in darkened, aerated aquaria under salinity conditions which the species encounters in nature (York River water, salinity $17.2 \% 0$ ). Five to eight animals were measured at $5^{\circ} \mathrm{C}$ intervals over the range $2 \cdot 5-27 \cdot 5^{\circ} \mathrm{C}$. The $\underline{b}$ values for the relationship between oxygen consumption and body weight found by Hoffman and Mangum (1970) at 10 and $20{ }^{\circ} \mathrm{C}$ were used to correct the data to a common weight of $4.0 \mathrm{gm}$, chosen because of its proximity to the sample mean. At $10^{\circ} \mathrm{C}$ the calculated $\underline{b}$ value $=-0.470$ (the correlation coefficient $\underline{r}=$ $0.527)$ and at $20^{\circ} \mathrm{C} \underline{b}=-0.542(\underline{I}=0.732)$; the difference between the two is not significant $(P>0.05)$, indicated by the overlap of $95 \%$ confidence intervals. To minimize temperature shock during the exposure period, the 2.5 and $7.5^{\circ} \mathrm{C}$ measurements were made during the coldest months, January and February, measurements at 17.5 and $12.5^{\circ} \mathrm{C}$ were made in late November and December, and the higher ones in March and April.

\section{Amphitrite ornata}

Worms were collected from the shores of the causeway. at Beaufort, North Carolina, in February when the mean monthly water temperature is 90 (Kirby-Smith and Gray, 1971). Animals were also obtained in the spring from the supply 
Department, Woods Hole, and exposed to 5, 10, 15, 20, and $25^{\circ} \mathrm{C}$ during the months Narch through May. Oxygen consumption rates were plotted as a function of oxygen concentrations to characterize the effect of oxygen concentration on the species' aerobic metabolism. The slopes of the linear regression lines describing the linear relationship of oxygen consumption and oxygen concentrations were used to compare rates at $100 \%$ saturation according to the covariance method (Steel and Torrie, 1960). A $\underline{b}$ value $(-0.955 ; \underline{r}=0.898)$ was calculated at $10^{\circ} \mathrm{C}$ for the relationship of oxygen consumption rates $(\mathrm{N}=8)$ at $100 \%$ air saturation and body weights of Massachusetts and North Carolina animals. To test the validity of the calculated $\underline{b}$ values at $10^{\circ} \mathrm{C}$ over a wide temperature range, a second logarithmic regression analysis of data from Massachusetts animals was made at $20^{\circ} \mathrm{C}(\mathrm{N}=8)$. At $20^{\circ} \mathrm{C} \underline{b}=0.869(\underline{r}=0.863)$. There is no significant difference $(P>0.05)$ between these values, indicating the homogeneous nature of the two slopes. At each temperature, active and resting metabolic rates were derived from 5-8 animals from Massachusetts only at the common weight of $3.50 \mathrm{gm}$.

II. Ventilatory behavior of Amphitrite ornata Worms were placed in U-shaped tubes whose diameters exceeded those of the animals by only several millimeters. Spontaneous irrigation cycles were recorded on a kymograph drum in an apparatus similar to that described by Mangum (1970). The tubes were oriented vertically to simulate the 
worm's natural position and recordings were made from either the anterior or posterior end of the animal. A large darkened lucite aquarium maintained at a constant water level by running sea water, housed the recording chamber.

A total of 122 hours of recordings from 11 animals was analyzed for the mean frequency, duration, and amplitude of bursts of pumping activity. By simulating activities of the worms with the addition of known volumes of water from below the recording chamber, the records were empirically calibrated and flow rates calculated (Dales et al., 1970).

\section{Statistical methods}

Differences between means for active and resting rates at each temperature were compared according to Student's $\underline{t}$ test.

For each species $Q_{10}$ values over $5^{\circ} \mathrm{C}$ temperature intervals were tested for their significance against the null hypothesis that $Q_{10}=1.0$. This test, devised by $W$. Van Winkle (personal communication), is assumed to follow the distribution for the $\underline{t}$ statistic. The test is

$$
t=\frac{\Delta T \log Q_{10}}{10 \sqrt{2} V \log R}
$$

where $V \log R$ is the pooled variance ( $V$ ) for $\log$ oxygen consumption rates $(R)$, and $T$ is the temperature.

A similar test, also devised by Van Winkle (personal communication), was used to test the significance between active and resting $Q_{10}$ values over the same temperature interval. This test iss

$$
t=\frac{\Delta T\left(\log _{10} 0_{A}-\log _{10} 0_{B}\right)}{20 V \log R}
$$




\section{RESUITS}

\section{Oxygen consumption}

Continuous recordings of oxygen depletion by Diopatra cuprea and Glycera dibranchiata in airtight chambers reflect the patterns of rest and activity described by Mangum and Sassaman (1969) and Hoffman and Mangum (1970) for the spontaneous behavior of these animals. Recordings of the ventilatory cycles of $\underline{D}$. cuprea in glass tubes are similar to those found in sand (Mangum et al., 1968). The frequency of rapid and slow rates of metabolism observed in $\underline{G}$. dibranchiata at $22.5^{\circ} \mathrm{C}$ closely agrees with that for bursts of activity at $23^{\circ} \mathrm{C}(0.70 \pm 0.04 / \mathrm{hr}$; Hoffman and Mangum, 1970). Because most oxygen consumption measurements for G. dibranchiata were made between 09.00 and $19.00 \mathrm{hr}$. , active and resting rates determined in this study probably correspond to the first and second of the four discrete metabolic levels detected by Mangum and Miyamoto (1970) at $21.8-23.8^{\circ} \mathrm{C}$. It is also interesting to note the agreement between $Q_{10}$ values for bursts of activity in $\underline{D}$. cuprea reported by Dales et al. (1970) and those we found for active metabolism in the same species over the temper-. ature range $12.5-22.5^{\circ} \mathrm{C}$. Beyond that interval, $Q_{10}$ values for active metabolism are somewhat higher than those for ventilation frequencies, although activity measurements 
were not made above $25^{\circ} \mathrm{C}$. Resting metabolism for the three species generally varies from 20 to $25 \%$ of the active metabolic rate.

over $5^{\circ} \mathrm{C}$ temperature intervals, all of the $Q_{10}$ values for $D$. cuprea, eight of the ten values for $G$. dibranchiata, and five of the eight values for $\mathrm{A}$ ornata are significantly greater than $1.0(P<0.05)$. With a few exceptions temperature change affects both active and resting metabolism to a similar degree. Significantly different $(P<0.05) Q_{10}$ values for both metabolic phases were observed only over the temperature interval $27.5-32.5^{\circ} \mathrm{C}$ in D. cuprea, which may indicate different responses of active and resting metabolism as the upper lethal limit above $32.5^{\circ} \mathrm{C}$ (Mangum and Sassaman, 1969) is approached. Q10 values for active and resting metabolism at the highest temperature interval in G. dibranchiata and at the lowest interval in A. ornata are not significantly different $(P>0.05)$. Finally, the magnitude of most of the $Q_{10}$ values resembles those found in maldanid polychaetes where no discrimination between active and resting metabolism was made (Mangum, 1963).

II. Ventilatory behavior of Amphitrite ornata

Between 18.0 and $19.8^{\circ} \mathrm{C}$ the mean frequency ( rhythmic activity bursts is $0.58 \pm 0.08 / \mathrm{hr}$. , the duration is $64.74 \pm 7.36 \mathrm{~min} .$, and the amplitude is $4.76 \pm 0.70 \mathrm{~cm} . \ldots$ deflection recorded on the kymograph drum. The rate of flow calculated from empirically calibrated records is $74.6 \mathrm{ml} / \mathrm{hr}$. Under existing temperature and salinity (31-32\%) conditions, 
the seawater contains around $5.5 \mathrm{ml} 0_{2} / 1$. making $0.418 \mathrm{ml}$ $0_{2} / \mathrm{hr}$. available to the animal. Based on the mean of active and resting metabolism at $20^{\circ} \mathrm{C}, a 3.5 \mathrm{gm}$. animal consumes $0.210 \mathrm{ml} /$ worm $/ \mathrm{hr}$. Therefore, the oxygen utilization rate is about 50\% which agrees closely with that $(50-60 \%)$ reported by Dales (1961) for three other terebellid species. Fig. 4 is a kymograph recording of the spontaneous behavior patterns of $A$. ornata. 
Fig. 1. R-T curves for active and resting metabolism in Diopatra cuprea. $Q_{10}$ values given for each interval; vertical bars represent standard error. 


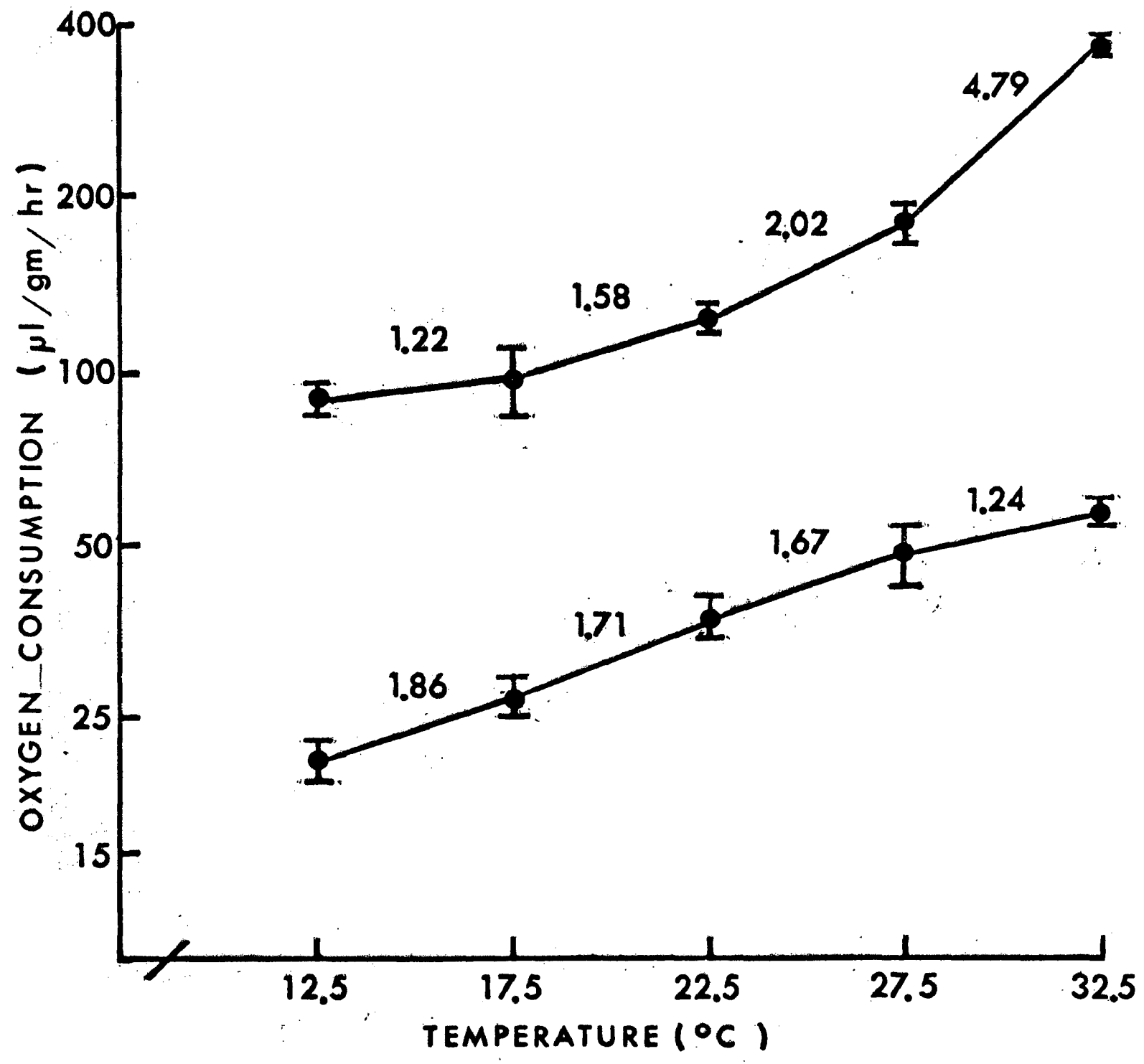


Fig. 2. R-T curves for active and resting metabolism in Glycera dibranchiata. Q10 values given for each interval; vertical bars represent standard error. 


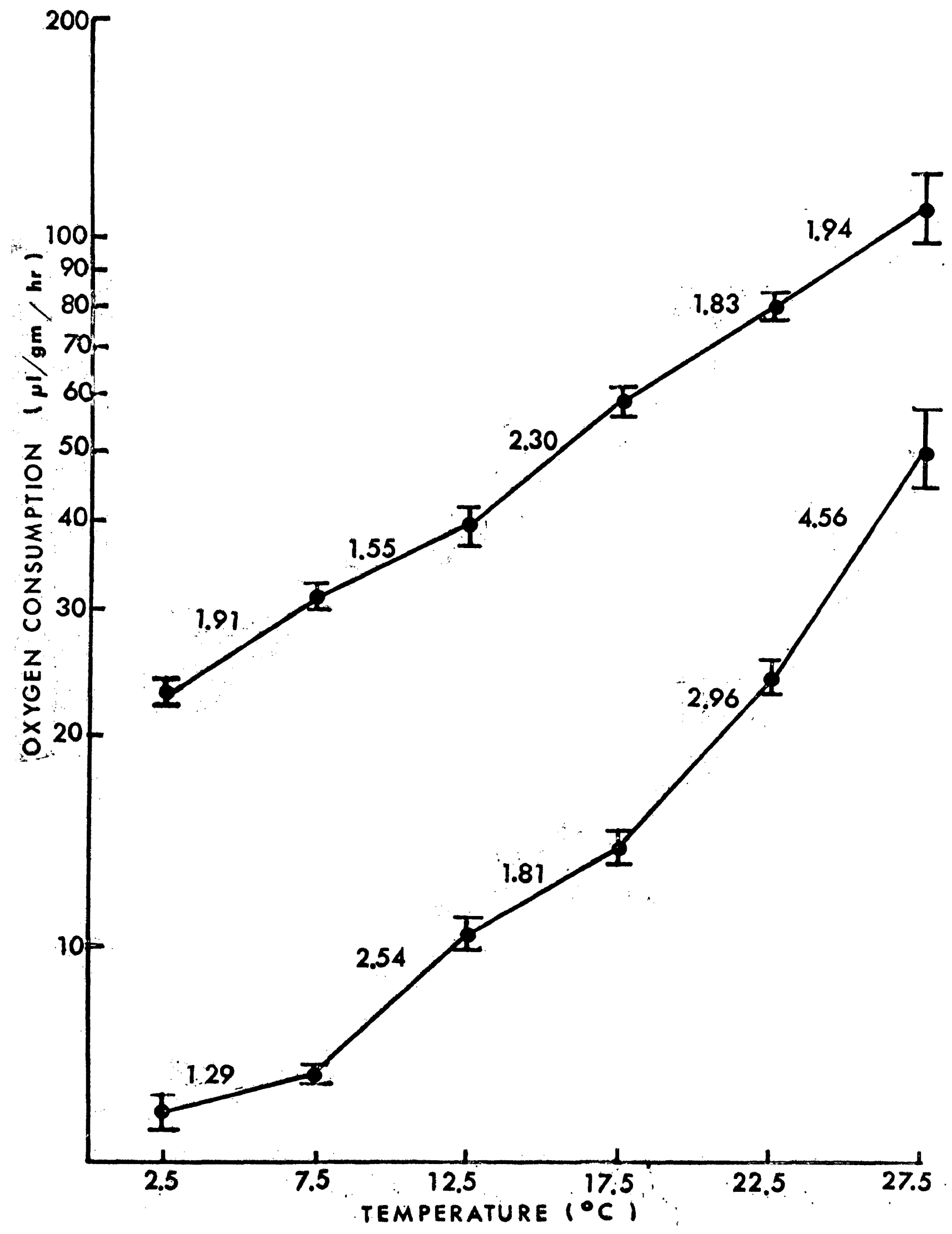


Fig. 3. R-T curves for active and resting metabolism in Amphitrite ornata. Q10 values given for each interval; vertical bars represent standard error. 


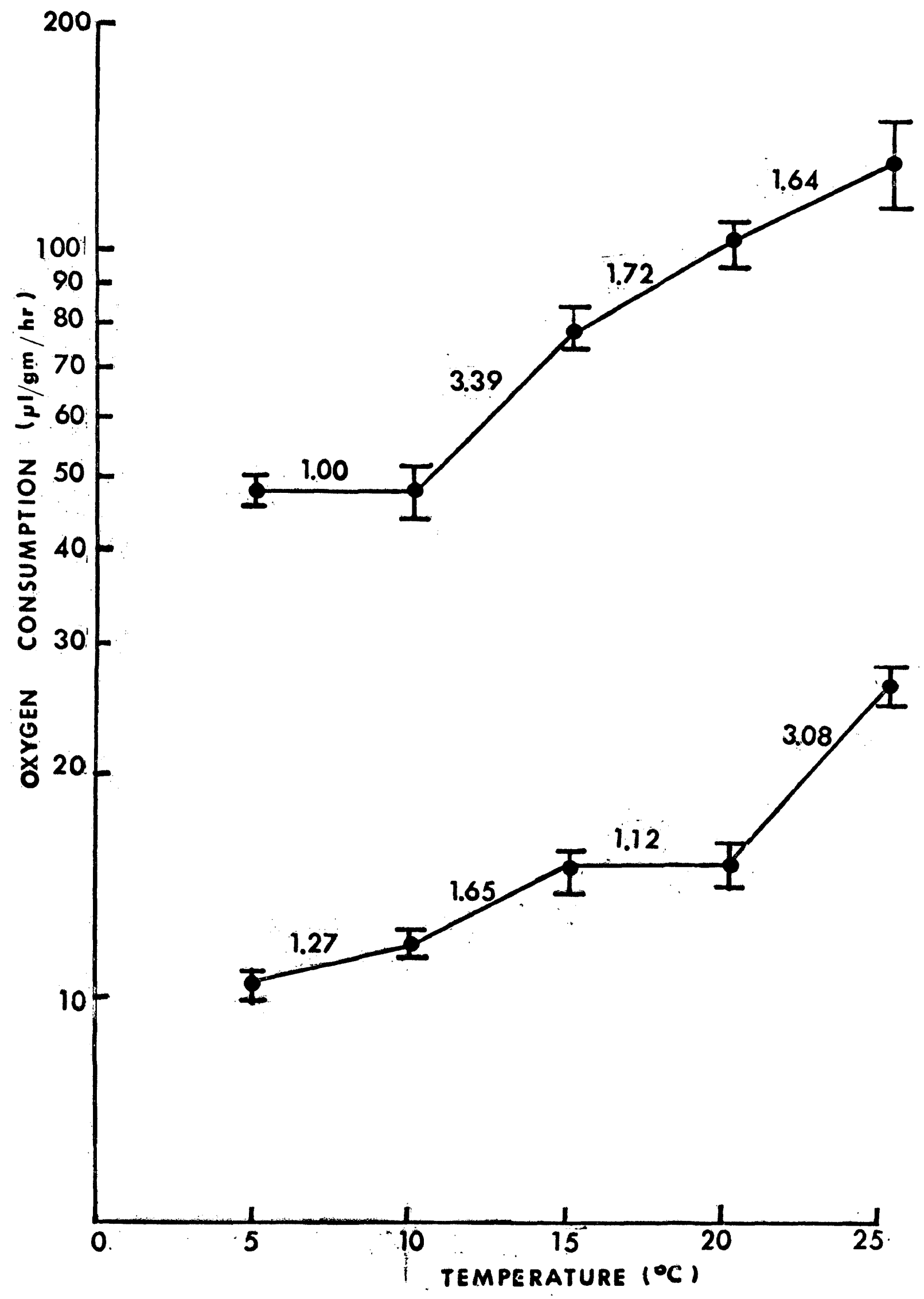


Fig. 4. Kymograph record of ventilation frequencies in Amphitrite ornata. Duration, $8.46 \mathrm{hr}$. ; temperature, $18.5^{\circ} \mathrm{C}$. 


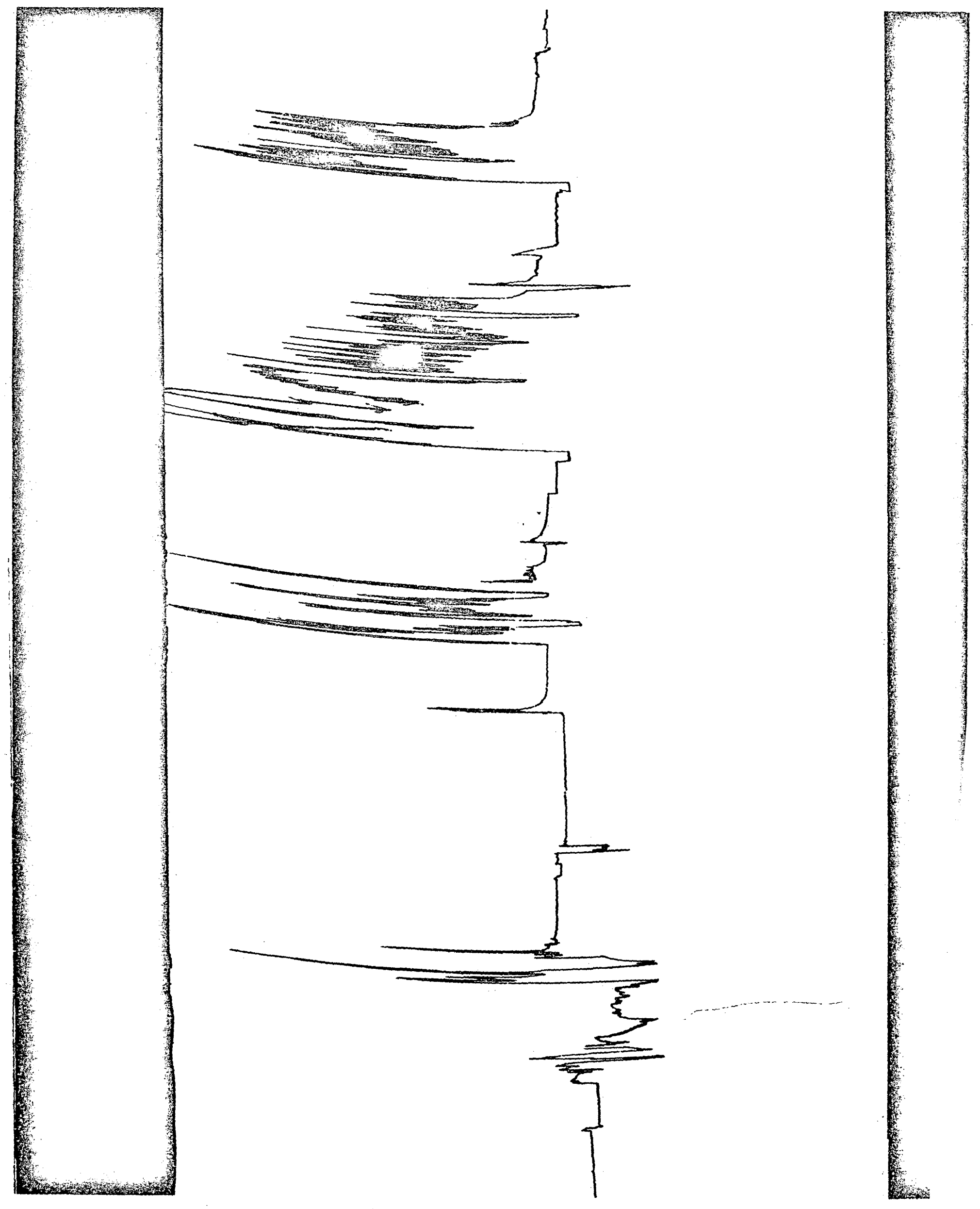




\section{DISCUSSION}

In our studies, neither active nor resting metabolism remained thermally insensitive over broad temperature ranges which these intertidal species encounter in nature. There is, in fact, no evidence from our data to support the existence of a mechanism operating at the whole animal level that reduces the effects of temperature. While low thermal sensitivity of metabolism over a small temperature range might be explained by the mechanisms proposed by Hochachka, (1968) and Somero and Hochachka, (1971), one would not expect these mechanisms be operative over temperature ranges as large as $20^{\circ} \mathrm{C}$.

An intrinsic weakness in many investigations of active and resting metabolism is the untested assumption that high and low measured levels of metabolism correspond to high and low levels of muscular activity. Fry (1957) and Tribe and Bowler (1967) discussed the necessity of measuring metabolic rates associated with quiescent behavior directly without unnatural extrapolation. Many different approaches to the problem of measurement have been employed, including two recent onesi Lowe and Trueman (1972) arrived at a low activity level of metabolism for Mya arenaria defined by reduced gill flow and heart rates, but they were forced to employ oxygen concentrations less than $20 \%$ air saturation 
in order to induce it. Thus the participation of anaerobic pathways may have been appreciable. The resting metabolism described by Wallace $(1972)$ is that of the shore crab measured in air. Q10 values for this rate are temperature sensitive, but they may reflect only the response of aerial and not aquatic respiration.

Aquatic annelids are especially suitable for direct measurement because active and resting metabolic rates are normal correlates of spontaneous rhythmic activity. Unlike actinians in which respiratory rates do not reflect different phases of activity, probably because the energy expenditure in maintaining the retracted phase is so small (Sassaman and Mangum, 1970), parameters of rhythmic activity cycles in annelids can be correlated directly with those of aerobic respiration. Periods of activity and rest can be detected in recordings of both respiration and spontaneous behavior of Amphitrite ornata. Frequencies for bursts of activity independently observed in ventilation and oxygen depletion records agree closely in magnitude. And both active and resting metabolic rates for $\underline{A}$. ornata and the two other polychaete species are clearly sensitive to temperature change. 
REFERENCES

1. Dales, R.P.: Oxygen uptake and irrigation of the burrow by three terebellid polychaetes Eupolymia, Thelepus, and Neoamphitrite. Physiol. Z0ol. 34, 306-311(1961).

2. Dales, R.P., Mangum, C.P. and Tichy, J.C.: Effects of changes in oxygen and caxbon dioxide concentrations on ventilation rhythms in onuphid polychaetes, $\mathrm{J}$. Mar. Biol. Ass. IJ.K. 50, 365-380(1970).

3. Fry, F.E.J.: The aquatic respiration of fish. physiology of Fishes, p. 1-63. New York Academic Press 1.957 .

4. Halcrow, $K_{0}$ and Boyd, C.M.s The oxygen consumption and swimming activity of the amphipod Gammarus oceanicus at different temperatures. Comp. Biochem. Physiol. 23. $233-242(1967)$.

5. Hochachka, P.W. Action of temperature on branch points in glucose and acetate metabolism. Comp. Biochem. Physiol. 25, 107-118(1968).

6. Hoffman, R.J. and Mangum, C.P.: The function of coelomic cell hemoglobin in the polychaete Glycera dibranchiata. Comp. Biochem. Physiol. 26, 211-228(1970).

7. Johnson, R.G.: Temperature variation in the infaural environment of a sand flat. Iimnol. Oceanogr. 10, $114-120(1965)$.

8. Kirby-Smith, W.W. and Gray, I.E.: A Checklist of Common Niarine Animals of Beaufort, North Carolina. Duke University Marine Laboratory 1971.

9. Lowe, G.A. and Trueman, E.R. The heart and water flow rates of Mya arenaria(Bivalvia:Mollusca) at different metabolic levels. Comp. Biochem. Physiol. 41, 487494(1972).

10. Mangum, C.P.: Studies on speciation in maldánid polychaetes of the North American coast-III. Intra- and inter-specific divergence in oxygen consumption. Comp. Biochem. Physiol. 10, 335-344(1963). 
11. Mangum, C.P.: Respiratory physiology in annelids. Amer. Sci. 58, 641-647(1970).

12. Mangum, C.P.: Temperature sensitivity of metabolism in offshore and intertidal onuphid polychaetes. Mar. Biol. (in press).

13. Mangum, C.P. and Miyamoto, D.M.: The relation between spontaneous activity cycles and diurnal rhythms of metabolism in the polychaetous annelid Glycera dibranchiata. Mar. Biol. 2, 7-10(1970).

14. Mangum, C.P. and Sassaman, C.s Temperature sensitivity of active and resting metabolism in a polychaetous annelid. Comp. Biochem. Physiol. 20, 111-116(1969).

15. Mangum, C.P., Santos, S.L. and Rhodes, W.R.: Distribution and feeding in the onuphid polychaete Diopatra cuprea (Bosc). Mar. Biol.2, 33-40(1968).

16. Newell, R.C.8 Oxidative activity of poikilothermic mitochondria as a function of temperature. J. Zool. 151, 277-298(1967)。

17. Newe11, R.C. and Northcroft, H.R.: A re-interpretation of the effect of temperature on the metabolism of certain marine invertebrates. J. Zool. 151, 277-298 (1967).

18. Nimura, $Y_{\text {. and Iroue, }} M_{*}:$ oxygen uptake rate of the Japanese spiny lobster as related to the environmental oxygen concentration. Bull. Jap. Soc. Sci. Fisheries 25. $852-861$ (1969).

19. Sassaman, C. and Mangum, C.P.: Patterns of temperature adaptation in North American Atlantic coastal actinians. Mar. Biol. 2, 123-130(1970).

20. Somero, G.N. and Hochachka, P.W.: Biochemical adaptation to the environment. Amer. Z001. 11, 157-165(1971).

21. Steel, R.G. and Torrie, J.H.: Principle and Procedures of Statistics. New York :McGraw-Hill 1960.

22. Tribe, M.A. and Bowler, $\mathrm{K}_{.}:$Temperature dependence of "standard metabolic rate" in appoikilotherm. Comp. Biochem. Physiol. 25, 427-436(1968).

23. Wallace, J.D.: Activity and metabolic rate in the shore crab Carcinus maenae( $\left.E_{\cdot}\right)$ Comp. Biochem. Physiol. 41, $523-533(1972)$. 


\title{
VI'TA
}

\section{Philip Exton Coyer}

\author{
Born May 20, 1948, in Harrisburg, Pennsylvania. \\ Graduated from Cedar Cliff High School, Camp Hill, \\ Pennsylvania, June 1966, A. B., Franklin and Marshal1 \\ College, 1970. N.S.F. summer research assistant at Franklin \\ and Marshall, 1968. Entered the College of William and \\ Mary fall of 1970 as a graduate assistant in the Department \\ of Biology. Recipient of a College Graduate Fellowship, \\ 1971. During the summer of 1972, acted as N.S.F. research \\ assistant to Dr. Charlotte P. Mangum at the Marine Biolog- \\ ical Laboratory, Woods Hole.
}

